\title{
CONVERSATIONAL COMPETENCES MODEL FOR INFORMATION TECHNOLOGY AND BUSINESS STRATEGIC ALIGNMENT
}

\author{
MODELO DE COMPETENNCIAS CONVERSACIONAIS PARA O ALINHAMENTO \\ ESTRATÉGICO ENTRE TECNOLOGIA DA INFORMAÇÃO E NEGÓCIO
}

\section{Luís Kalb Roses}

Universidade Católica de Brasília, Brasília/DF, Brasil

Jean Carlos Borges Brito

Faculdade Projeção, Brasília/DF, Brasil

Gentil José de Lucena Filho

LabCon - Laboratório de Conversas, Brasília/DF, Brasil

\begin{abstract}
The main objective of this study is the development of a model of conversational competences for Business and IT managers aiming at the strategic alignment between their areas. The theory of this alignment highlights the importance of communication between Business and IT areas, which is explored in the social dimension of their managers' relationship through conversational competences. A survey research was performed with Business and IT managers from public and private organizations in Brazil, whose data were analyzed through multivariate statistical techniques exploratory and confirmatory factor analysis - and thematic content analysis. The results confirmed the constructs and most of the hypotheses of the proposed research model, which was expanded with new constructs and hypotheses.
\end{abstract}

Keywords: IT and Business strategic alignment. Communication. Social dimension. Strategic Conversations. Conversational competences.

Manuscript first received/Recebido em: 04/02/2014 Manuscript accepted/Aprovado em: 11/11/2014

Address for correspondence / Endereço para correspondência

Luís Kalb Roses, Professor Doutor, SGAN Quadra 916, Módulo B, Sala A138, Av. W5 Norte, Brasília (DF), CEP 70790-160, Universidade Católica de Brasília, e-mail: 1kroses@ gmail.com.

Jean Carlos Borges Brito, Professor Mestre, Área Especial nº5 e 6, Setor C Norte, Taguatinga (DF), CEP 72115-700, Faculdade Projeção, e-mail: zuluaer@gmail.com.

Gentil José de Lucena Filho, Professor Doutor e Diretor-Executivo de Pesquisa do LabCon Laboratório de Conversas, Condomínio Ville de Montagne, Quadra 32, Lote 43, Jardim Botânico, Lago Sul, Brasília (DF), CEP 71680-357, e-mail: gentil@labconbrasil.com. 


\section{RESUMO}

O objetivo principal deste estudo é o desenvolvimento de um modelo de competências conversacionais aos gestores de TI e Negócio para o alinhamento estratégico entre as suas áreas. A teoria desse alinhamento destaca a importância da comunicação entre as áreas de TI e Negócio, que na sua dimensão social é explorada neste estudo sob o enfoque das competências conversacionais no relacionamento entre os seus gestores. Foi realizada pesquisa survey junto a esses gestores em organizações públicas e privadas localizadas no Brasil, cujos dados foram analisados por meio de técnicas estatísticas multivariadas - análise fatorial exploratória e confirmatória - e análise de conteúdo temática. Os resultados da pesquisa confirmaram os construtos e a maioria das hipóteses do modelo de pesquisa proposto, que foi expandido com novos construtos e hipóteses.

Palavras-chave: Alinhamento estratégico TI e Negócio. Comunicação. Dimensão social. Conversas estratégicas. Competências conversacionais.

\section{INTRODUCTION}

In this study, the strategic alignment between Business and Information Technology (IT) within organizations, or Business-IT alignment, can be seen as the degree to which the information technology mission, objectives, and plans support and are supported by the business mission, objectives, and plans (Reich and Benbasat, 2000). It is also how IT is aligned with Business and vice versa (Business is aligned with IT), promoting the efficient growth of investments in IT (Luftman, 2000; Mithas, Tafti, Bardhan and Goh, 2012). Such an alignment has been identified as one of the major concerns of IT managers (Luftman and Zadeh, 2011; Ullah and Lai, 2013).

Over time, research on Business-IT alignment has favored its intellectual dimension (analysis of strategies, structures and planning methods) over its social dimension (Reich and Benbasat, 2000; Tan and Gallupe, 2006; Chan, 2007), which is where its causes of lack of success are (Rigoni, 2010; Abib, Hoppen and Rigoni, 2012; Silva, Luft, Cavalcante and Freitas, 2013). This dimension investigates the actors within organizations, their values and communication, which will be reflected on the mutual understanding between business and IT managers when representing their area mission, objectives and plans (Rigoni, 2010).

It is a fact that IT managers taking part in Business planning has affected both IT and Business planning content (Tan and Gallupe, 2006), influencing the organizations' competitiveness (Kearns and Lederer, 2003). However, this participation needs to be encouraged through the communication between Business and IT managers, which strengthens interconnected relationships between these two areas (Henderson and Venkatraman, 1993; Rezende, 2002; Brodbeck and Hoppen, 2003). In this regard, Chan (2002) highlights communication as a requirement for Business-IT alignment, both in formal and informal structures of the organization. After all, communication is an essential element in social interaction (Giddens, 1984).

Research has highlighted communication in the Business-IT alignment process (Reich and Benbasat, 2000; De Haes and Van Grembergen, 2008; Yayla and Hu, 2009; Johnson and Lederer, 2009; Silvius, De Haes and Van Grembergen, 2009; Chong, Chan, Ooi and Darmawan, 2011), which is an evaluation criteria (Luftman, 2000) and a weak aspect (Luftman, 2000; Rigoni; Hoppen; Santana, 2007; Reinhardt and Bigueti, 2013) in this alignment. The success of the business depends largely on 
the efficacy, efficiency and flexibility of the internal organizational communication, as everything that happens in the organization depends on it (Malmelin, 2007; Chong et al., 2011).

Communication of meanings in social interactions takes place by means of interpretative patterns, which add meaning to what each participant says and does. The use of these cognitive patterns, in the context of mutual knowledge, depends on and is developed under a "cognitive order" shared by a community which reestablishes this order (Garfinkel, 1967; Giddens, 1993; Scott, 2001). Thus, it is noted the interdependence between communication and cognition in social interactions. After all, conveying information and sharing knowledge through this interdependence occur in a social dimension of spoken interaction, or as conversations, in this study.

Studies about conversations in organizational communication are not new (Gratton and Goshal, 2002; Mengis and Eppler, 2008; Lima, Filion, Dalfovo and Junior, 2013; Martins, 2013). However, studies about conversations in Business-IT alignment are not common. This fact encourages further research on how communication takes place in the Business-IT alignment process (Johnson and Lederer, 2009) through the conversations between Business and IT managers. In this context, the following research question is relevant in this study: What is the influence of conversational competences on Business and IT strategic alignment? In order to answer it, the objective of this study is the development of a model of conversational competences for IT and Business managers aiming at the strategic alignment between their areas.

\section{STRATEGIC CONVERSATIONS}

Studies by Von Krogh and Roos (1995) reveal that conversations between Business and IT managers have strategic characteristics as they focus on the development of the organization and create the future of the Business, as they project and distribute resources for this future. According to Chermack, Van Der Merwe and Lynham (2007), a strategic conversation is a phenomenon composed of a set of conversations, interactions and dialogs, which take place daily and between the members of an organization, in formal and informal situations.

An effective strategic conversation requires a common language, the alignment of ideas, the engagement in rational argumentations, and the development of ideas within an organization (Heijden, 2005). A common language is achieved through the mutual understanding of the speakers in a conversation, taking its jargon and context into careful consideration. Therefore, Business managers must speak a language that IT managers understand and vice versa.

The development of ideas within an organization is the objective of the strategic conversation, aiming at the development of a common language in the alignment of ideas, with the opportunity to criticize and to be criticized in a constructive manner. After all, there is no absolute truth and a manager may have an opinion about and understanding of something that has not been perceived by the other manager, as each one of them is from a different field of work and skill set (Lima et al., 2013). The opportunity for constructive feedback helps managers reach an agreement on the subject in question.

Urbanavicius and Lima (2014) found that strategic conversations between comanagers, despite their influence on strategic practices, are started by those who like to talk. Thus, according to these authors, enjoying a conversation must be an 
important characteristic of leaders, or managers, so that their strategic conversations happen and their results achieved, based on strategic guidance (mission, vision and goals) towards conducting business and, consequently, Business-IT alignment.

Thus, through strategic conversations, it is possible to contribute to BusinessIT alignment (Reich and Benbasat, 2000). In this regard, strategic conversations are expected to have a positive influence on Business-IT alignment, from the perspective of both Business and IT, as such a strategic alignment between these two areas must be considered from the perspective of each one of them (Kearns and Lederer, 2003). Then, the following hypotheses are developed:

H1a - Strategic conversations between Business and IT managers have a positive influence on Business-IT alignment from IT perspective; and

H1b - Strategic conversations between Business and IT managers have a positive influence on Business-IT alignment from Business perspective.

\subsection{CONVERSATIONAL COMPETENCES}

A good level of communication between Business and IT managers results from a good relationship between them (Jorfi, Nor and Najjar, 2011). Whenever the relationship between Business and IT is more active, due to meetings, workshops and informal conversations, the alignment is more effective as a consequence of a shared understanding through communication (Abib and Hoppen, 2012). Pinto and Graeml (2011) support this fact when they relate the late involvement of IT managers in discussions about strategies and new products to rework and the lack of IT optimization to enable these new products.

A good relationship between Business and IT arises from conversational competences in the development of their strategic conversations. Competence is a word that originates from daily experiences and lifestyle people have in society, being used to show that a person is competent enough to perform a task (Fleury and Fleury, 2001). Dacoreggio (2006) states that a competence is only recognized when it is available; that is, for a manager, whether from IT or Business, there is no point in simply knowing that he knows how to talk and how to be a good listener. This manager needs to show, in particular, that he is aware of the distinctions in conversational competences through his daily experiences, values, skills and attitude, in order to receive the due recognition from the other manager.

Flores and Winograd (1989), Kofman (2001) and Echeverria (2008) highlight the following conversational competences, relevant in this study: commitments, effective listening, and productive explanations and questions. Conversational commitments establish common goals and joint actions between Business and IT, when IT is committed to support and sustain Business strategic objectives, while Business is committed to invest in technological infrastructure whenever IT projects are a priority. Thus, the use of a common language must be pursued, through clear and objective explanations so that speakers can understand what is explained. In this context, effective listening and productive explanations and questions are conversational competences that characterize effective communication and help in the development of that common language (Kofman, 2001).

\subsubsection{Commitments}

Commitments are conversational competences which can aid in reducing the gap found in the interactions between Business and IT managers, described by 
Luftman and Brier (1999) as commitments and promises which are not fulfilled by IT. Business areas depend on services and systems provided by IT in order to automate and speed up their processes. Business managers, when making projections and plans for the future of the organization, notice that their individual efforts are not enough to achieve Business objectives, as they need to develop partnerships with IT managers in order to make commitments of interest between them.

Flores and Winograd (1989) state that commitments are made for those who speak and for those who listen, through speech acts. Commitments made between Business and IT managers foster common objectives and joint actions between their areas. Kofman (2001) asserts that a conversation based on commitments has the purpose of appointing whoever is responsible for what, how, when, the purpose and to whom something is assigned to. This group of actions impacts future expectations, which will require their coordination and leveling between the people involved in them.

Kofman (2001) says that when certain people make a request, an offer or a promise, they do not express through words the current state of the world, as these speech acts are used to express the purpose and the obligation of making the future state of the world to be aligned with such words. Through promises, a future course of action is proposed, that is, a new world is created and whoever makes a promise declares their commitment to fulfilling certain obligations in the future. Managers may even delegate some tasks to other individuals so that a promise is fulfilled; however, responsibility can not be assigned to someone else (Kofman, 2001).

Based on the aforementioned, this study regards commitments, through requests, offers and promises, as one of the required conversational competences from Business and IT managers. Although requests, offers and promises are part of the negotiation dialogue between managers, these three components characterize the commitments made between them, through the demand (request), its respective solution (offer) and the conditions of execution (promise). Thus, commitments have a positive influence on the strategic conversations between them and on the strategic alignment between their areas, from the perspective of each one of them, as stated in the following hypotheses:

H2a-Commitments between Business and IT managers have a positive influence on strategic conversations between these areas;

H2b-Commitments between Business and IT managers have a positive influence on Business-IT alignment from IT perspective; and

H2c-Commitments between Business and IT managers have a positive influence on Business-IT alignment from Business perspective.

\subsubsection{Effective Communication}

Mastering and controlling the conversation elements, or spoken communication, lead to an effective communication through encouraging dialogs, direct conversations and face-to-face communication in order to achieve organizational objectives (Martins, 2013). From the studies by Kofman (2001), this study regards an effective communication as a dimension that encompasses conversational competences of effective listening and of productive explanations and questions. In the conversations between Business and IT managers, they must be careful and verify whether what they said was heard the way they had intended it to be, reducing reasons for disagreements and conflicts. 
It is necessary to make a distinction between hearing and listening, as the former is a biological phenomenon related to the perception of sounds, and the latter belongs to mastering a language and is composed of people's social interactions, contributing to understanding and interpretation (Echeverria, 2008). Thus, effective listening is a conversational competence which can contribute to the development of teamwork, through partnerships such as the ones between IT and Business managers.

An effective communication requires that IT managers observe the perspective from which Business managers are expressing themselves and vice versa. Whenever necessary, they must make corrections of distorted mutual conceptions through productive explanations and questions, which need to be used jointly so that they have an effective communication, contributing to effective listening. For effective listening, managers must allow the other speaker to explain themselves and then ask questions productive explanations and questions (Echeverria, 2008). This helps Business and IT managers understand each other, sustaining their judgments and creates facts that make sense.

Productive explanations help Business and IT managers to reveal and find solutions to differences they have in knowledge, reasoning and purposes (Kofman, 2001). Productive questions is the way to observe other people's logical capacity, helping them explain not only their thoughts, but also their reasons (Kofman, 2001). Therefore, productive explanations and questions create an environment of cooperation, bring down barriers and make possible the coordination of actions towards the benefit of the collective, reducing some gaps found in the interactions between Business and IT manages (Luftman and Brier, 1999; Reich and Benbasat, 2000; Tan and Gallupe, 2006; Bassellier and Benbasat, 2007; De Haes and Van Grembergen, 2008).

Communication in which managers only explain or question, even if they are skillfully made, is not effective. (Kofman, 2001). Productive explanation must be aligned with productive questions, as ritualized conversations come from the isolated use of these skills (Gratton and Goshal, 2002). After all, commitments are made based on a common language, which comes from competences such as effective listening, and productive explanations and questions, all related to an effective communication. Thus, the following hypotheses are developed:

H3a - Effective communication between Business and IT managers has a positive influence on Business-IT alignment from IT perspective;

H3b-Effective communication between Business and IT managers has a positive influence on Business-IT alignment from Business perspective;

H3c - Effective communication between Business and IT managers has a positive influence on strategic conversations they have; and

H3d - Effective communication between Business and IT managers has a positive influence on commitments between them.

\subsection{PROPOSED RESEARCH MODEL}

Figure 1 shows the proposed conversational competences model with the developed hypotheses in this study, aiming at Business-IT alignment, where it is possible to see the positive influence of conversational competences - effective communication (effective listening, productive explanations, and productive questions) and commitments (requests, offers, and promises) - on strategic 
conversations between Business and IT managers; from these strategic conversations on Business-IT alignment, from the perspective of each of these two areas (according to the perspective, the related area is in bold and underlined); and from an effective communication between them on the their commitments, in the domain of conversational competences required from them.

Figure 1 - Conversational competences model in Business-IT strategic alignment

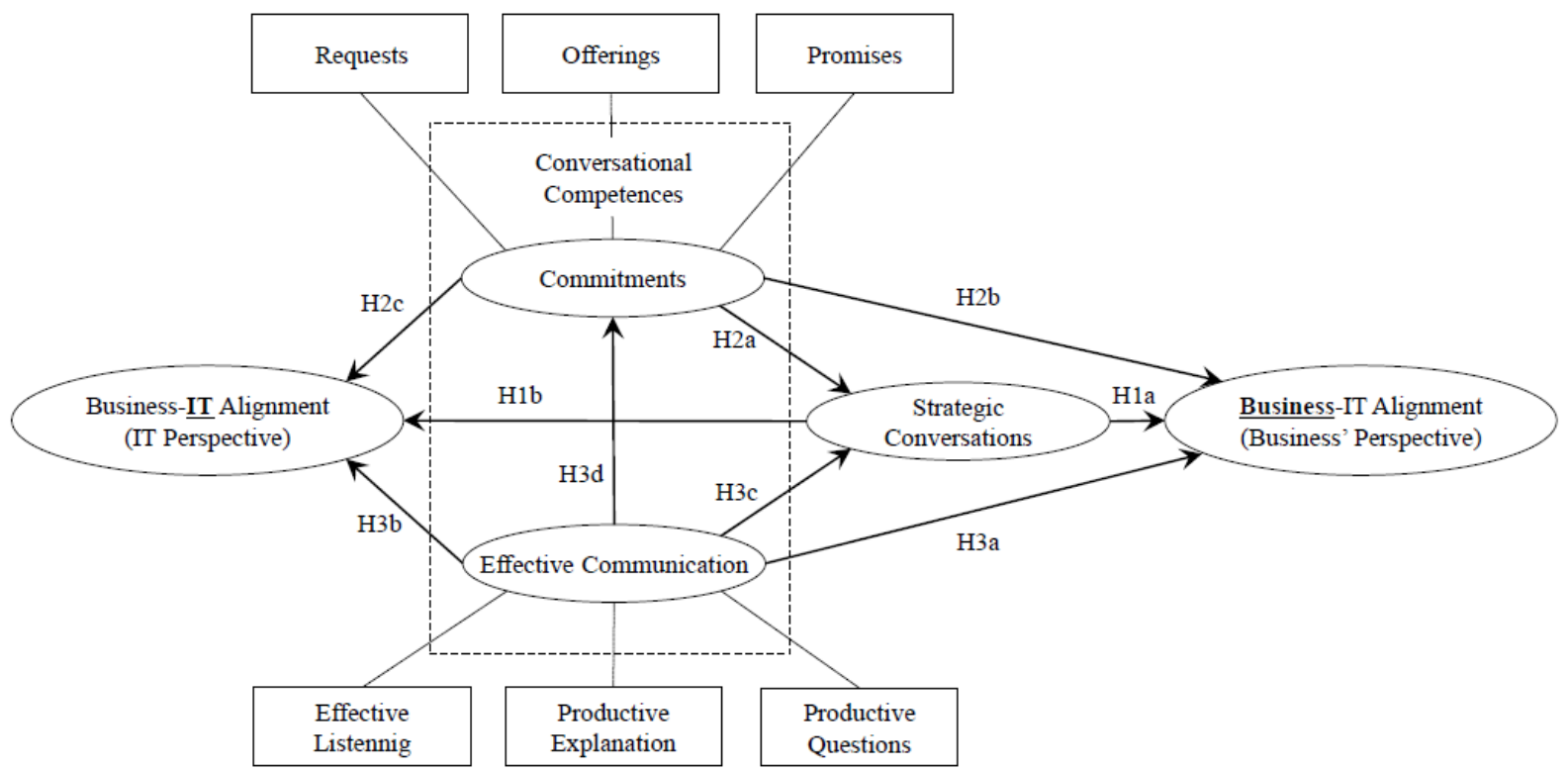

Despite the fact it is an evaluation model of such influences at a certain moment, in a static perspective of Business-IT alignment (Chan and Reich, 2007), it does not misrepresent the characteristics of the continuous process required from the Business-IT alignment dynamics (Brodbeck and Hoppen, 2003; Chan and Reich, 2007). After all, relationships are sustained in the many exchange situations that arise from the daily organizational conversations between IT and Business managers.

\section{METHODOLOGY}

This exploratory descriptive research uses a survey strategy, which is characterized by the application of a structured research instrument in order to obtain the respondents' perceptions, which are representatives of a sample of a population (Malhotra, 2009).

\subsection{RESEARCH INSTRUMENT}

The research instrument used was a questionnaire with 50 questions, divided into three parts: I) eight demographic questions related to the respondent and their work organization; II) 41 closed questions, which evaluate respondent perceptions based on a Likert-type scale of seven points, where the first item (1) of the scale refers to strong disagreement, the last one (7) to strong agreement, and the other items between them ( 2 - disagree; 3 - slightly disagree; 4 - neutral; 5 - slightly agree; and 6 - agree); and III) an open question (item A1), in which respondents were asked to give their opinions about the importance of the conversations between Business and IT managers in the Business-IT strategic alignment process.

Regarding the composition of the part II of the research instrument, items 1, 2, 27, 28 and 29 are related to strategic conversations, as presented by Von Krogh and Roos (1995), Chermack et al. (2007), Lima (2007), Mengis and Eppler (2008) and Heijden (2005); items 3 to 8 to effective listening, as defined by Kofman (2001) and 
Echeverria (2008); items 9 to 14 to productive explanations, based on Kofman (2001); items 15 to 20 to productive questions, as presented by Kofman (2001); items 21 to 26 to commitments, based on Flores and Winograd (1989), Kofman (2001) and Echeverria (2008); items 30 to 35 to Business-IT alignment from IT perspective, according to the instrument developed by Kearnes and Lederer (2003) and also used by Tan and Gallupe (2006); items 36 to 41 to Business-IT alignment from Business perspective, based on the instrument developed by Kearnes and Lederer (2003) and also used by Tan and Gallupe (2006).

As items 30 to 41 were taken from an existing instrument developed in English, they were translated by means of back translation with the help of two people fluent in English and in Portuguese, when the necessary adjustments were evaluated by the author and by an expert in IT governance. The face validity of the instrument was done with the support of 20 senior professionals (for instance, managers, system analysts, engineers, accountants, mathematicians). Some adjustments were made in the research instrument, which was submitted to a pre-test with four respondents. This process resulted in small improvements in the final version of the instrument, which was submitted to a pilot test with two different respondents, when it was deemed suitable to the research.

\subsection{RESPONDENTS AND DATA COLLECTION PROCEDURES}

The respondents of the target population of the research were Business and IT managers from public and private organizations in Brazil, based in the cities of Brasilia (Federal District) and Rio de Janeiro (Rio de Janeiro State). These cities were chosen by convenience, as they have a high concentration of public organizations and companies from a variety of economic sectors, which, in this research, were those from such sectors as aerospace, legal, technological, financial, education, healthcare, energy, pension, consultancy, intelligence, logistic, and auditing. The number of employees of these organizations ranged from 83 (the lowest) to 110.000 (the highest). Two of the organizations have operations abroad.

The sampling method in the research was the accidental non probability type, which, according to Bisquerra, Sarriera and Martinez (2004), chooses its individuals based on certain criteria, aiming at representativeness through the resulting sampling. The authors highlight that this procedure is often used in situations in which the sample of individuals is based on the ease of access, being a particular case the use of volunteers. Therefore, it is not possible to generalize the results of the sample to a larger population than the analyzed one, as it is not possible to calculate the sampling error and, consequently, the ideal representativeness of the sample.

26 organizations were researched, through emailing the research instrument to the employees contacted by the researcher (or research facilitators), so that they could forward it to potential respondents from their respective organizations, that is, Business and IT managers. Other research facilitators, related to three different organizations, preferred to receive a hard copy of the research instrument. Therefore, 29 public and private organizations took part in the research.

The distribution of the research instruments started on June $14^{\text {th }}, 2010$, and the deadline for the submission of answers was July $9^{\text {th }}, 2010$, which was then extended to two different dates (August $7^{\text {th }}, 2010$ and August $30^{\text {th }}, 2010$ ) due to the low number of answers received. 113 research instruments answered were received from 24 organizations, which $59.8 \%$ were public ones and $40.2 \%$ private ones. Six of them were rejected by the target population criterion - or Business and IT managers from 
strategy and tactics segments -, whereas 107 were accepted - or $36.89 \%$ of the total defined population (290).

\subsection{DATA ANALYSIS}

For the initial storage of the data, a Microsoft (MS) Excel® spreadsheet was used to save research answers from closed questions and open question, as well. From this spreadsheet, the answers of closed items were imported to the SPSS ${ }^{\circledR}$ software, version 17 . These quantitative data were analyzed by means of second generation multivariate analysis, using the exploratory factor analysis (EFA), through SPSS itself, and the confirmatory factor analysis (CFA), through Amos ${ }^{\circledR}$, version 16.

Although the open question were optional (item A1), 30 answers were chosen, (28.03\% of the sample), based on the rules of exhaustion, representativeness and relevance (Bardin, 2009). These answers were saved in a MS Excel spreadsheet so that all the material was organized before the beginning of the analysis. Next, thematic content analysis (TCA) was applied with "boxes" procedure based on a system of categories composed of commitments, effective communication and strategic conversations. This system was not regarded as exhaustive, with regard to restricting the discovery of new categories during the analysis (Miles and Huberman, 1994).

\section{RESULTS AND ANALYSES}

The respondents' demographic profile was distributed as follows: a) $79.4 \%$ are male and $20.6 \%$ female; b) 9,3\% have a higher education degree and 90.7 have a postgraduation degree; c) $65.1 \%$ have a degree in exact sciences, $30.2 \%$ have degree in human sciences and $4.7 \%$ have a degree in these two areas; d) as for how long they have been working as managers in their organizations, $26.2 \%$ have been for only 5 years, $29.9 \%$ from 5 to 10 years and $43.9 \%$ for more than 10 years, which characterizes the respondents' work experience as managers; e) as for how long they have been working in their organizations, $19.6 \%$ for up to 5 years, $22.5 \%$ between 5 and 10 years and $57.9 \%$ for more than 10 years; $f$ ) as for the position as a manager, $8.4 \%$ are directors, $8,4 \%$ are advisors, $57 \%$ are executive managers and $26.2 \%$ are in new management positions; and g) $61.7 \%$ are IT managers, while $38.3 \%$ are Business managers $(15.9 \%$ from area that supports the core business $22.4 \%$ from the core business area).

\subsection{DATA EXAMINATION AND PREPARATION}

Prior to the application of the EFA, the data were examined and carefully prepared, as the extreme or typical questions may have a negative influence on the result of these analyses, requiring data adjustment (Hair, Anderson, Tatham and Black, 1998). Thus, the data was prepared following these steps: univariate scatter plot examination; identification of the missing data and outliers, taking univariate and multivariate detections into consideration; and verification of the normality, homoscedasticity, and linear relationship.

The occurrence of missing data (up to $1.9 \%$ by variable) was within the $3 \%$ acceptable limit of the sample (Cohen, Cohen, West and Aiken, 2003). In the univariate analysis, outliers were not identified, that is, observations had a standard deviation greater than 3 (Hair et al., 1998) - the values found were between 0.292 and 1.74. In the multivariate analysis, the $D^{2}$ Mahalanobis distance measure was used (Tabachnick and Fidel, 2001), being identified 13 outliers $-12.14 \%$ of the cases and having as limits critical values to $\chi^{2}$ with $p<0,001$.Characteristics that could justify their exclusion were not found. 
Normality hypothesis was not confirmed for frequency distribution of the metric variables observed (items 1 to 41), a situation confirmed by the K-S test (Kolmogorov-Smirnov) for normality. As a consequence, homoscedasticity was not observed either, which occurs when two or more distributions show equivalent dispersions (Bisquerra, Sarriera and Martinez, 2004).

Thus, data transformation took place next (Hair et al., 1998), through exponentiation calculation, and results closer to normality were obtained for many variables, despite the fact it was not achieved, but contributing to homoscedasticity. The symmetry and asymmetry of the distribution curves were improved, showing variation of -0.655 to 0.233 , and kurtosis showing variation of 1.711 to -0.337 . Asymmetry lower than 3 and kurtosis lower than 8 are acceptable values (Kline, 1998).

The linear relationship between two variables is evaluated by means of bivariate scatter plot analysis (Tabachnick and Fidell, 2011). The five most normal variables were analyzed (P41, P39, P38, P36 and P35) as well as the five least normal (P11, P3, P17, P24 and P22), two by two, with no curvilinear relationship observed. The correlation matrix values are enough to justify the use of the factor analysis, as the visual inspection shows a substantial number greater than 0.30 (Tabachnick and Fidell, 2011). In addition, a correlation matrix with MSA (measure of sampling adequacy) - or degree of correlation between variables - greater than 0.80 will be worthy to recognition.

\subsection{EXPLORATORY FACTOR ANALYSIS}

The EFA by components ( $\mathrm{R}$ Factor Analysis) was adopted, aiming to summarize most of the original information (variance) in a minimum number of factors for prediction purposes. This is necessary to represent most of the variance in the original set of variables, in addition to the fact that specific variance and errors represent a small portion of the total variance.

\subsubsection{Identification of Factors and General Alignment}

In the definition of the number of unrotated factors to be extracted, the latent root (eigenvalues) criterion was used, being chosen factors with eigenvalue greater than 1 . When the total number of variables is between 20 and 50 , this criterion is recommended in order to establish a more reliable cutoff point (Hair et al., 1998), which is the case in this research (41 variables). Factors (components) chosen were those that obtained eigenvalues greater than 1 and represented $70.561 \%$ of the cumulative variance, that is, factors $1,2,3,4,5,6,7,8,9$ and 10.

Percentage variance criterion has the approach of achieving specific cumulative percentage out of the total variance extracted by successive factors. The purpose is to ensure practical significance for the derived factors, ensuring that they may explain a specific amount of variance. There is no absolute threshold adopted for all applications, and percentage from $60 \%$ to $95 \%$ is regarded as satisfactory in some areas of study (Hair et al., 1998). The selection of the 10 factors was supported by the Scree test, which highlights the number of the most representative factors.

\subsubsection{Interpreting the Factors}

After the identification of the 10 factors with the unrotated factor matrix, the orthogonal rotation method was applied. It simplifies the factor structure and has an adequate analysis to interpret the variables and their contributions across each factor, 
whereas oblique rotation method is not well developed and is subject to considerable controversy (Hair et al., 1998). In the orthogonal rotation, the varimax method was used as it simplifies the columns of the factorial matrix and provides transparency in the way the factors are arranged.

Hair et al. (1998) state that a cutoff point of \pm 0.55 or greater is relatively high and may be adjusted if necessary. A value greater than 0.40 was established as a cutoff point for each variable. In the EFA with $\mathrm{R}$ factor Analysis, the first component (factor) explains most data variability, which, in this analysis, is approximately $28.04 \%$ and, as a consequence, the variables are going to be more correlated to it. The following variables were excluded from the analysis as they represent complex items, that is, factor loadings in more than one factor: var_trans_p2, var_trans_p5, var_trans_p15, var_trans_p16 and var_trans_p25.

Reliability tests were performed for each factor, by means the calculation of Crombach's Alpha coefficient. Factors 6 and 8 were excluded, due to their low reliability in relation to the reference value, that is, lower than 0.70 . It was not possible to calculate Crombach's Alpha coefficient for factors 7, 9 and 10, as each one of them has just one variable. Thus, the variables related to these values were also excluded from the analysis.

Unidimensionality problems were not detected (Hair et al., 1998), as the variables of a factor did not relate to concepts outside the origin factor (dimension or construct). From the defined codebook, which is composed of the characteristics and purpose of measuring each variable, the selected factors were defined as follows: factor 1 - effective communication (EFCOM); factor 2 - Business-IT alignment, from Business perspective (BUSITA); factor 3 - Business-IT alignment, from IT perspective (ITBUSA); factor 4 - commitments (COMMT); and factor 5 - strategic conversations (SC).

\subsection{CONFIRMATORY FACTOR ANALYSIS}

In the CFA, by means of structural equation modeling, the maximum likelihood estimation procedure was adopted, which is more common and recommended when the minimum size of the sample ranges from 100 to 150 (Hair et al., 1998), situation of this research.

\subsubsection{Research Model Fit}

The research model fit was analyzed through three measure sets (Hair et al., 1998): a) absolute fit measures, which judges the model fit (structural and measuring); b) incremental fit measures, when the proposed model is compared with another null model; and c) the parsimonious fit measures, which measure the model by estimated parameter. The application of multiple measures provides consensus to the acceptance of the research model.

Table 1 shows the examined indexes, that is: a) chi-square $\left(\chi^{2}\right)$; b) degrees of freedom (DF); c) chi-square divided by degrees of freedom $\left(\chi^{2} / \mathrm{DF}\right)$; d) RMSEA (root mean square error of approximation); e) CFI (comparative fit index); f) NFI (normed fit index); g) IFI (incremental fit index); h) TLI (Tucker-Lewis index); and i) Hoelter. Absolute fit measures were below the required limits, both for the RMSEA value (0.06 $<0.08)$ and for $\chi^{2 / G L}(1.43<3)$. 
136 Roses, L. K., Brito, J. C. B., Lucena Filho, G. J. de

Table1 - Model fit indexes

\begin{tabular}{c|c|c}
\hline Model fit indexes & Desired Values & Achieved Values \\
& (Kline, 1998; Hair et al., 1998; Kenny, 2014) & 487.831 \\
\hline$\chi^{2}$ & - & 341 \\
\hline DF & - & 1.43 \\
\hline$\chi^{2}$ DF & $<3$ & 0.75 \\
\hline NFI & $>.90$ & 0.90 \\
\hline TLI & $>.90$ & 0.906 \\
\hline CFI & $>0.90$ & 0.908 \\
\hline IFI & $>0.90$ & 0.06 \\
\hline RMSEA & $<0.08$ & 84 \\
\hline Hoelter .05 index & $>75$ & 88 \\
\hline Hoelter .01 index & $>75$ & 0.906 \\
\hline
\end{tabular}

From the incremental fit measures, the required minimum value $(0.90)$ was not achieved by NFI (0.75) and TLI (0.90), although the former was slightly lower and the latter at the same value, while CFI (0.906) and IFI (0.908) exceeded the minimum limit value. As the $\chi^{2}$ statistics are significant, the Hoelter index was used, which indicates the size of the sample in which $\chi^{2}$ would not have been significant $(\alpha=0.01$ and $\alpha=0.05$ ), when values greater than 75 indicates a satisfactory fit of the sample. Thus, the research model was accepted as an acceptable representation of the established constructs (effective communication; Business-IT alignment, from both IT and Business perspectives; commitment; and strategic conversations).

Regarding the construct validity (convergent and discriminant validity), the convergent validity may be verified through the analysis of the factor loadings of the items that compose the construct. The one that shows strong $(\beta>0.5)$ and significant $(\mathrm{p}<0.000)$ factor loadings has this validity (Steenkamp and Van Trijp, 1991; Hair, Anderson, Tatham and Black, 2005), a situation which was observed in all the model constructs. Discriminant validity is achieved by means of comparison of the shared variance $\left(\mathrm{r}^{2}\right)$ between the constructs and the average variance extracted from each construct, when the latter is greater than the former.

According to Table 2, the correlation between the constructs ranged from $r_{\text {minimum }}$ of 0.220 (EFCOM-ITBUSA) and the $r_{\text {maximum }}$ of 0.609 (ITBUSA-BUSITA), as per the average variance extracted, diagonally highlighted. From the analyzed data, it is then possible to infer that the model contains discriminant validity and that all the constructs are distinct. Finally, composite reliability coefficients are considered to be accepted if they are greater than 0.70 and the extracted variances greater than 0.50 (Kline, 1998; Hair et al., 2005), which is the case in this study. This can be seen in Table 3, which indicates that, in addition to being valid, the scale is reliable.

Table 2 - Comparison between shared and extracted variance

\begin{tabular}{|c|c|c|c|c|c|}
\hline & $\overline{\text { EFCOM }}$ & BUSITA & ITBUSA & COMMT & ST \\
\hline EFCOM & 0.666 & 0.361 & 0.220 & 0.553 & 0.480 \\
\hline BUSITA & 0.361 & 0.793 & 0.609 & 0.276 & 0.461 \\
\hline ITBUSA & 0.220 & 0.609 & 0.736 & 0.254 & 0.487 \\
\hline COMMT & 0.553 & 0.276 & 0.254 & 0.720 & 0.533 \\
\hline SC & 0.480 & 0.461 & 0.487 & 0.533 & 0.613 \\
\hline
\end{tabular}

Table 3 - Composite reliability and extracted variance 


\begin{tabular}{c|c|c}
\hline \multicolumn{2}{c}{ Composite reliability (>0.70) } & Extracted Variance (>0.50) \\
\hline EFCOM & 0.87 & 0.666 \\
\hline BUSITA & 0.91 & 0.793 \\
\hline ITBUSA & 0.89 & 0.755 \\
\hline COMMT & 0.84 & 0.720 \\
\hline SC & 0.70 & 0.613 \\
\hline
\end{tabular}

\subsubsection{Analysis of the Hypotheses}

According to the statistics provided by the CFA, when the dependent construct was strategic conversations, there was an influence from effective communication $(\beta=0.27 ; p<0.05)$ and commitments $(\beta=0.50 ; p<0.001)$, being the latter the most relevant of the two previous ones. When the dependent construct was commitment, it was influenced by the effective communication construct $(\beta=0.55 ; p<0.000)$. The strategic conversations construct was the one that showed the greatest effects on the Business-IT alignment constructs, both from IT perspective $(\beta=0.91 ; p<0.000)-$ or Business-IT alignment (IT in bold and underlined) - and from Business perspective ( $\beta=0.80 ; p<0.000)$ - or Business-IT alignment (Business in bold and underlined). Table 4 shows the results of the hypotheses testing.

Table 4 - Hypothesis analysis of the proposed research model

\begin{tabular}{c|c|c|c|l|l}
\hline Hyp. & Independent Construct & Dependent Construct & Result & \multicolumn{1}{c}{$\boldsymbol{p}$-value } \\
\hline $\mathrm{H} 1 \mathrm{a}$ & Strategic conversations & Business-IT alignment & Supported & 0.91 & $p<0.000$ \\
\hline $\mathrm{H} 1 \mathrm{~b}$ & Strategic conversations & $\underline{\text { Business-IT alignment }}$ & Supported & 0.80 & $p<0.000$ \\
\hline $\mathrm{H} 2 \mathrm{a}$ & Commitments & Strategic conversations & Supported & 0.50 & $p<0.001$ \\
\hline $\mathrm{H} 2 \mathrm{~b}$ & Commitments & Business-IT alignment & Rejected & -0.27 & $p=\mathrm{NM}$ \\
\hline $\mathrm{H} 2 \mathrm{c}$ & Commitments & $\underline{\text { Business-IT alignment }}$ & Rejected & -0.30 & $p<0.07$ \\
\hline $\mathrm{H} 3 \mathrm{a}$ & Effective communication & Business-IT alignment & Rejected & -0.12 & $p=\mathrm{NM}$ \\
\hline $\mathrm{H} 3 \mathrm{~b}$ & Effective communication & $\underline{\text { Business-IT alignment }}$ & Rejected & 0.09 & $p=\mathrm{NM}$ \\
\hline $\mathrm{H} 3 \mathrm{c}$ & Effective communication & Strategic conversations & Supported & 0.27 & $p<0.05$ \\
\hline $\mathrm{H} 3 \mathrm{~d}$ & Effective communication & Commitments & Supported & 0.55 & $p<0.000$ \\
\hline $\mathrm{N}$ & & & &
\end{tabular}

Notes: $\boldsymbol{\beta}=$ standardized beta coefficients; and NM = not meaningful.

By analyzing the variables of conversational competences, the evidence did not show a significant effect of the commitments construct on the Business-IT alignment constructs, that is, from IT perspective $(\beta=-0.27 ; p<\mathrm{NS})$ and from Business perspective $(\beta=-0.30 ; p<0.07)$. Similarly, the effective communication construct did not show a significant effect on the same constructs, that is, in IT perspective ( $\beta=-$ $0.12 ; p=\mathrm{NS})$ and in Business perspective $(\beta=0,09 ; p=\mathrm{NS})$. Thus, the improvement in the effective communication (effective listening, productive explanations and productive questions) between Business and IT managers has a high impact on commitments and strategic conversations, which will affect the Business-IT alignment directly within organizations, from the perspective of both of these areas.

\subsection{THEMATIC CONTENT ANALYSIS}

The TCA confirmed the ex-ante categories defined in theory, according to the examples of IT managers (ITM) and Business managers (BM) statements, in Table 5. Conflict resolution and judgments were identified in the TCA as new categories 
related to conversational competences, as shown in Table 6, according to those managers' statements.

Table 5 - Statements related to previously defined categories

\begin{tabular}{|c|c|c|c|}
\hline \multicolumn{3}{|r|}{ Statements } & \multirow{2}{*}{ Manager } \\
\hline \multirow{2}{*}{\multicolumn{2}{|c|}{ 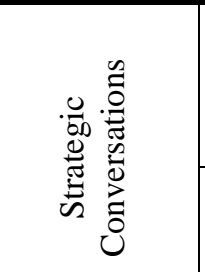 }} & $\begin{array}{l}\text { - More dialogues are necessary between Business and IT managers; and } \\
\text { - Business and IT managers do not use a common language, which makes it } \\
\text { difficult for Business managers to understand what is said. }\end{array}$ & \\
\hline & & $\begin{array}{l}\text { - Conversations are few and difficult to access; and } \\
\text { - Lack of knowledge sharing and synchronism. }\end{array}$ & ITM \\
\hline \multirow{2}{*}{\multicolumn{2}{|c|}{ : }} & $\begin{array}{l}\text { - Conversations between IT and Business managers take place in a negotiation } \\
\text { context of requests to IT area, when commitments are made by this area to Business } \\
\text { areas; and } \\
\text { - IT difficulties to give proper support to Business in the meeting of deadlines. }\end{array}$ & ITM \\
\hline & & $\begin{array}{l}\text { - Business areas do not set more realistic deadlines for IT; and } \\
\text { - Business areas do not discuss between them what their priorities are. }\end{array}$ & $\mathrm{BM}$ \\
\hline \multirow{4}{*}{ 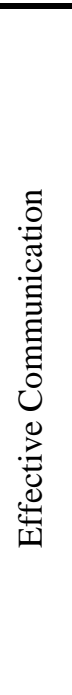 } & \multirow{2}{*}{ 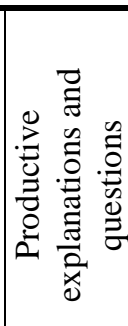 } & $\begin{array}{l}\text { - Managers impose their opinions, there is no convergence; and } \\
\text { - IT managers are more inclined to take their perception of the Business needs into } \\
\text { consideration than prioritizing the considerations of the Business areas themselves. }\end{array}$ & $\mathrm{BM}$ \\
\hline & & $\begin{array}{l}\text { - Business areas prioritize their needs, but do not worry about how IT will meet } \\
\text { their demands; and } \\
\text { - IT managers do not know the Business areas. }\end{array}$ & ITM \\
\hline & \multirow{2}{*}{ 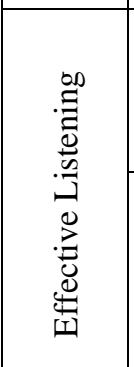 } & $\begin{array}{l}\text { - IT managers must take a helpful position towards Business managers, } \\
\text { understanding their problems and needs; and } \\
\text { - A mutual integration between Business and IT managers is necessary. }\end{array}$ & BM \\
\hline & & $\begin{array}{l}\text { - Change in IT position towards understanding of Business demands, } \\
\text { specifications and needs; and } \\
\text { - IT managers take a defensive position, blaming the Business area for not being } \\
\text { clear and objective in their demands. }\end{array}$ & ITM \\
\hline \multicolumn{4}{|c|}{ Table 6 - Statements related to conflict resolution and judgments } \\
\hline \multirow{3}{*}{\multicolumn{2}{|c|}{ 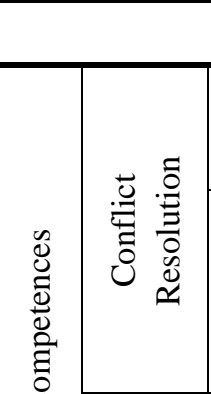 }} & Statements & Manager \\
\hline & & $\begin{array}{l}\text { - When they related to one another, there are not points of balance; and } \\
\text { - It's all or nothing. }\end{array}$ & $\mathrm{BM}$ \\
\hline & & $\begin{array}{l}\text { - There is controversy between managers when they try to understand one another; } \\
\text { and } \\
\text { - Business and IT managers must recognize their own limitations and together } \\
\text { make commitments aligned with their organization's strategic objectives. }\end{array}$ & ITM \\
\hline$\frac{0}{\tilde{\Xi}}$ & $\stackrel{0}{=}$ & $\begin{array}{l}\text { - IT is focused on the search for what is ideal and perfect, whereas Business does } \\
\text { not have basic functions addressed; and } \\
\text { - Supplier versus client relationship basis. }\end{array}$ & $\mathrm{BM}$ \\
\hline$\grave{\Xi}$ & 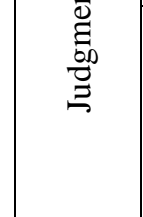 & $\begin{array}{l}\text { - Companies do not understand the real meaning of planning; } \\
\text { - Business managers blame IT area for the cause of many of their unsuccessful } \\
\text { cases; and } \\
\text { - Business Areas do not discuss between them what their priorities are. }\end{array}$ & ITM \\
\hline
\end{tabular}


Business managers declare that in their conversations with IT managers the conflicts are caused by misunderstandings, which in many cases cannot be resolved. They say that the IT position is, sometimes, inflexible and that communication takes place on a "all or nothing" basis, creating competitive work environments, whose conversations are developed as ritual and unhealthy (Gratton and Ghoshal, 2002). This type of conflicting relationship between managers is referred to as a direct consequence of the "interdependence between IT and Business", as the two of them "work in isolation, distant from one another". Admission of co-responsibility in conflict resolution between areas constitutes an important tool to overcome communication gaps (Kofman, 2001) and, therefore, the development of strategic conversations. This situation enables the following hypothesis:

H4 - Conflict resolution between Business and IT managers has a positive influence on strategic conversations between them.

Judgments are the verdict of certain actions or manifestations, that is, they are inherent to the human nature and occur throughout a conversation, whether explicit or not (Echeverria, 2008). They are two sided for the strategic conversation process: they may hurt a relationship between participants, if they are based on rigid and unquestionable assumptions, whenever they are mistakenly regarded as affirmative statements; and they may give rise to different points of view, when they improve information exchange between the speakers.

Expressing judgments is directly related to the observation of the past and of recurring attitudes, as, in general, judgments are regarded as naturally conservatives (Echeverria, 2008). Then, the assumptions presented by judgments must be accepted with caution so that they do not give rise to evasive and preconceived argumentations, excluding and prejudiced attitudes. Therefore, the following hypothesis is developed in this study:

H5 - Judgments between Business and IT managers have a positive influence on strategic conversations between them.

A way to support conflict resolution between Business and IT areas, as well to reduce the existence of negative judgments between them, is found in the effective communication between their managers. Thus, the following hypotheses are established in this study:

H3e - Effective communication between Business and IT managers has a positive influence on conflict resolution between them; and

H3f - Effective communication between Business and IT managers has a positive influence on the judgments between them.

\subsection{CONVERSATIONAL COMPETENCES MODEL}

Figure 2 shows the final conversational competences model of this study for Business and IT managers aiming at the strategic alignment between their areas. The results of the quantitative analysis confirmed the positive influence of strategic conversations on the Business-IT alignment from the perspective of IT (H1a) and of Business (H1b), which suggests a single construct for these two perspectives and, hence, a single hypothesis of positive influence of the strategic conversations on it (H1); of conversational competences on strategic conversations, through commitments (H2a) and of effective communications (H3c); and of effective communication on commitments (H3d). On the dotted lines, the new constructs identified in the 
qualitative analysis (conflict resolution and judgments) receive a positive influence from effective communication ( $\mathrm{H} 3 \mathrm{e}$ and $\mathrm{H} 3 \mathrm{f}$, respectively) and have a positive influence on strategic conversations ( $\mathrm{H} 4$ and $\mathrm{H} 5$, respectively), suggesting the extension of the conversational competences model initially proposed in this study for Business-IT alignment.

Figure 2 - Conversational competences model in the Business-IT strategic alignment

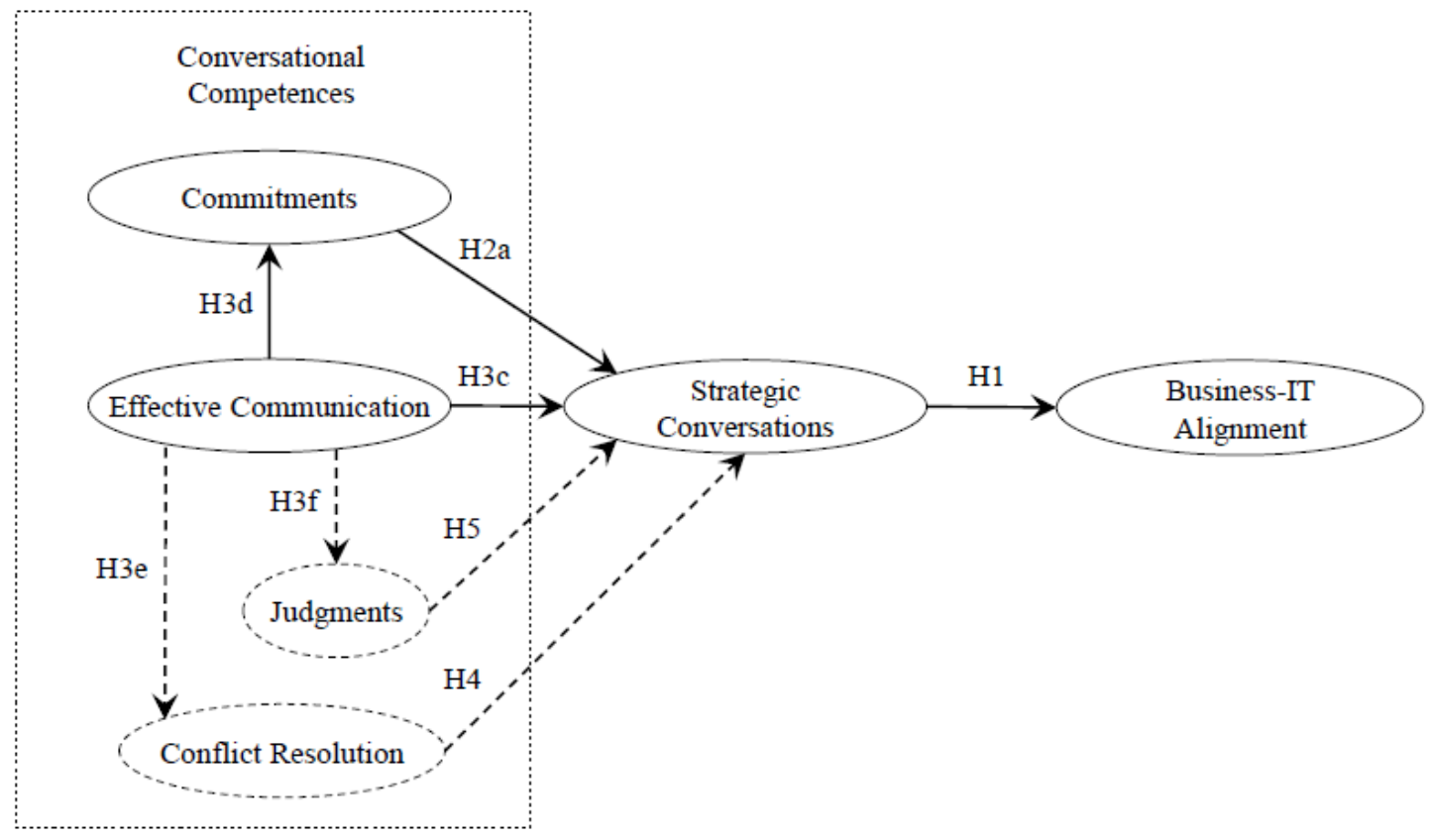

\section{FINAL CONSIDERATIONS}

This study identified the required conversational competences from Business and IT managers for the strategic alignment between their areas, from the social dimension perspective of this alignment. Initially, four conversational competences were described, based on the elements of a strategic conversation: effective listening and productive explanations and questions, which compose effective communication; and commitments, which is characterized by requests, offers and promises. These competences had a direct influence on the strategic conversations and an indirect one on the Business-IT alignment, from the perspective of these both areas. New conversational competences emerged in the content analysis: conflict resolution and judgments.

The final model of the research shows that, in the scope of conversational competences of IT and Business managers, an effective communication had a direct impact on the commitments made between Business and IT and on their strategic conversations, as well. As a consequence, strategic conversations, being influenced by effective communication and commitments, had a direct impact on the Business-IT alignment. It is possible to infer that conversational competences indirectly have an influence on Business-IT alignment. Evidence showed the validity and reliability of the research model through statistical techniques applied. In addition, the qualitative analysis confirmed the categories previously defined in the theory presented in this study.

This study offered theoretical contributions in the scope of Business-IT alignment, with an approach geared towards conversational competences. The 
intellectual dimension of this alignment has been favored in the research. This study explored its social dimension, highlighting the role of strategic conversations between Business and IT managers with conversational competences. From a pragmatic point of view, this research offers important results for the full development of Business and IT managers regarding conversational competences they must have for better alignment between their areas.

A limitation in this study relates to the fact that only four macro conversational competences were described, among other existing ones. This is justified by the definition of the research scope and by the decision of not burdening respondents with so many questionnaire items to answer. Thus, the most relevant competences to the communication between Business and IT managers were explored, in accordance with the theoretical framework here developed. Another limitation regards to the fact that the sampling was a non-probability one, which does not permit the generalization of results beyond the studied population.

As future research suggestions are the validity of the final model of this research by means of a survey research, due to the identification of new categories and hypotheses; the identification of other conversational competences, which may directly or indirectly influence the Business-IT strategic alignment; and the involvement of a larger scope of respondents and/or organizations, not only taking into account the managers, but also Business and IT teams, when conversations at both operational and tactical levels of these areas can be analyzed, as well their impact on the alignment between them.

\section{REFERENCES}

Abib, G., \& Hoppen, N. (2012). Do Discurso à Prática: O Papel da Dimensão Social no Processo de Alinhamento Estratégico. In: Proceedings of the $18^{\text {th }}$ Americas Conference on Information Systems (AMCIS), Washington, Aug. 9-12 ${ }^{\text {th }}$.

Abib, G., Hoppen, N., \& Rigoni, E. H. (2012). A Dimensão Social no alinhamento estratégico entre Negócio e TI. Revista Eletrônica de Sistemas de Informação, 11(1), $1-16$.

Bardin, L. (2009). Análise de Conteúdo. Trad. Luís Antero Reto e Augusto Pinheiro. $4^{a}$ e. Lisboa: Edições 70 Ltda, 2009.

Bassellier, G., \& Benbasat, I. (2007). Assessing the Contributions of Business and IT Knowledge to the Development of IT/Business Partnerships. St. Louis, Missouri, USA: ACM-SIGMIS-CPR'07, Apr.19-21.

Bisquerra, R., Sarriera, J. C., \& Martinez, F. (2004). Introdução à Estatística: Enfoque informático com o pacote estatístico SPSS. Porto Alegre: Artmed.

Brodbeck, A. F., \& Hoppen, N. (2003). Alinhamento Estratégico entre os planos de Negócio e de tecnologia da informação: um modelo operacional para implementação. Revista de Administração Contemporânea, 7(3), 9-33.

Chan, Y. E. Whey haven't we mastered alignment? The importance of the informal organization structure. (2002). MIS Quarterly, 1(2), 97-122.

Chan, Y. E., \& Reich, B. H. (2007). IT alignment: what have we learned? Journal of Information Technology, 22, 297-315. 
Chermack, T. J., Van Der Merwe, L., \& Lynham, S. A. (2007). Exploring the relationship between scenario planning and perceptions of strategic conversation quality. Technological Forecasting and Social Change, 74(3), 379-390.

Chong, A. Y.-L., Chan, F. T. S., Ooi, K.-B., \& Darmawan, N. (2011). Does employee alignment affect business-IT alignment? An empirical analysis. Journal of Computer Information Systems, 51(3), 10-20.

Cohen, J., Cohen, P., West, S. G., \& Aiken, L. S. (2003). Missing Data. In: Applied Multiple Regression/Correlation Analisys for the Behavioral Sciences. 3. e. New Jersey: Lawrence Erlbaum Associates, Cap. 11, 431-451.

Dacoreggio, M. dos S. (2006). Competências no contexto da ação docente: ressignificando o conceito. Contrapontos, 6(1), 49-64.

De Haes, S., \& Van Grembergen, W. (2008). Analysing the relationship IT governance and business/IT alignment maturity. In: Proceedings of the $41^{\text {st }}$ Hawaii International Conference on Systems Sciences.

Echeverria, R. (2008). Ontología Del Lenguaje. 1. e. Buenos Aires, Granica:Juan Carlos Saez Editor.

Fleury, M. T. L., \& Fleury, A. (2001). Construindo o conceito de competência. Revista de Administração Contemporânea, 5(spe), 183-196.

Flores, F., \& Winograd, T. Dirección y Conversación. (1989). In: Hacia la Comprensión de la Informática y la Cognición. Barcelona, Espanha: Hispano Europeia.

Garfinkel, H. (1967). Studies in Ethnomethodology. New Jersey: Prentice-Hall.

Giddens, A. (1984). The Constitution of Society. Berkeley; Los Angeles: University of California Press.

Giddens, A. (1993). New Rules of Sociological Method. Stanford (CA): Stanford University Press.

Gratton, L., \& Ghoshal, S. (2002). Improving the quality of conversations. Organizational Dynamics, 31(3), 209-223.

Hair, J. F. J., Anderson, R. E., Tatham, R. L., \& Black, W. C. (1998). Multivariate data analisys. $5^{\mathrm{a}}$ e., New Jersey: Prentice-Hall.

Hair, J. F. J., Anderson, R. E., Tatham, R. L., \& Black, W. C. (2005). Multivariate data analisys. $6^{\text {a }}$ e., New Jersey: Prentice-Hall.

Heijden, K. V. D. (2005). The Art of Strategic Conversation. 2. e., Chinchester: John Wiley \& Sons.

Henderson, J. C., \& Venkatraman, N. (1993). Strategic Alignment: Leveraging information technology for transforming organizations. IBM Systems Journal, 38(1), 4-16.

Johnson, A., \& Lederer, A. (2009). CEO/CIO Communication and the strategic grid dimensions. In: Tan, A. W. K, \& Theodorou, P. Strategic Information Technology and Portfolio Management. UK: IGI Global.

Jorfi, S., Nor, K. M., \& Najjar, L. (2011). The relationships between IT flexibility, ITBusiness strategic alignment, and IT capability. International Journal of Managing Information Technology, 3(1), 16-31. 
Kearns, G. S., \& Lederer, A. L. (2003). A resource-based view of strategic IT alignment: How knowledge sharing creates competitive advantage. Decision Sciences, 34(1), 1-29.

Kenny, C. M. (2014). Measuring model fit. Recovered in Jan. 31 ${ }^{\text {st }}$, 2014, from http://davidakenny.net/cm/fit.htm.

Kline, R. B. (1998). Principles and Practice of Structural Equation Modeling. New York: Guilford.

Kofman, F. (2001). Metamanagement: La nueva con-ciencia de los negócios. 1. e. Barcelona: Ediciones Granica, v. 2.

Lima, E. (2007). Visão compartilhada, equipe de direção e gestão estratégica de pequenas e médias empresas: um estudo multi-caso e internacional. Revista de Negócios, 12(4), 86-100.

Lima, E. D. O., Filion, L. J., Dalfovo, O., \& Junior, V. U. (2013). Gestão Estratégica e compartilhamento da visão em micro e pequenas empresas. Revista Ibero-Americana de Estratégia, 12(2), 12-41.

Luftman, J. (2000). Assessing Business-IT Alignment Maturity. Communications of the Association for Information Systems, 4(14), 1-50.

Luftman, J., \& Brier T. (1999). Achieving and Sustaining Business-IT Alignment. California Management Review, 42(1), 109-122.

Luftman, J., Zadeh, H. S. (2011). Key information technology and management issues 2010-2011: an international study. Journal of Information Technology, 26, 193-204.

Malhotra, N. K. (2009). Marketing Research: An Applied Orientation. $6^{\mathbf{a}}$ e., Englewood Cliffs, NJ: Prentice-Hall.

Malmelin, N. (2007). Communication capital modelling corporate communications as an organizational asset. Corporate Communication, 12(3), 298-310.

Martins, M. T. M. C. (2013). Diálogo e interações face a face:a força da oralidade na comunicação interna. Revista Organicom, 10(19), 184-198.

Mengis, J., \& Eppler, M. J. (2008). Understanding and Managing Conversations from a Knowledge Perspective: An Analysis of the Roles and Rules of Face-to-face Conversations in Organizations. Organization Studies, 29(10), 1287-1313.

Miles, M. B., \& Huberman, A. M. (1994). Qualitative Data Analysis: An Expanded Sourcebook. 2. ed. London, Thousand Oaks, New Delhi: Sage Publications.

Mithas, S., Tafti, A., Bardhan, I., \& Goh, J. M. (2012). Information technology and firm profitability: mechanisms and empirical evidence. MIS Quarterly, 36(1), 205224.

Pinto, G. J. S., \& Graeml, A. R. (2011). Revista de Gestão da USP, 18(2), 259-274.

Reich, B. H., \& Benbasat, I. (2000). Factors that influence the social dimension of alignment between business and information technology objectives. MIS Quarterly, 24(1), 81-113.

Reinhardt, N., \& Bigueti, J. R. (2013). The Influence of Shared Mental Models between the CIO and the Top Management Team on the Strategic Alignment of Information Systems: A Comparison between Brazilian and US Companies. Journal of Information Systems and Technology Management, 10(3), 503-520. 
Rezende, D. A. (2002). Alinhamento do Planejamento Estratégico da Tecnologia da Informação ao Planejamento Empresarial: Proposta de um modelo e verificação da prática em grandes empresas brasileiras. Florianópolis, 2002. 278 f. Tese (Doutorado em Engenharia de Produção - Gestão da Tecnologia da Informação) - Programa de Pós-Graduação em Engenharia de Produção, Universidade Federal de Santa Catarina, Florianópolis (SC).

Rigoni, E. H. (2010). Identificação de Relações de Importância entre Elementos de Maturidade de Alinhamento Negócios-TI e Tipos Estratégicos. Porto Alegre, 2010. 168 f. Tese (Doutorado em Administração) - Escola de Administração, Universidade Federal do Rio Grande do Sul, Porto Alegre (RS).

Rigoni, E. H., Hoppen, N., \& Santana, M. (2007). Um estudo cross-country da percepção do alinhamento estratégico entre negócio e tecnologia da informação. In: I Encontro de Administração da Informação (ENADI). Anais... Florianópolis (SC), 24 a 26 de out.

Scott, W. R. (2001). Institutions and Organizations. Thousand Oaks; London; New Delhi: Sage.

Silva, W. A., Luft, M. C. M. S., Cavalcante, F., \& Freitas, H. P. (2013). Repensando o Alinhamento Estratégico da TI: Perspectiva Crítica ao Discurso Hegemônico. In: $4^{\circ}$ Encontro Anual de Tecnologia da Informação (EATI). Anais... Frederico Westphalen (RS).

Silvius, A. J. G., De Haes, S., \& Van Grembergen, W. (2009). Exploration of cultural influences on Business and IT alignment. Proceedings of the 42nd Hawaii International Conference on System Sciences, Hawaii.

Steenkamp, J. B. E. M., \& Van Trijp, H.C.M. (1991). The use of Lisrel in validating marketing constructs. International Journal of Research in Marketing, 8(4), 283-299.

Tabachnick, B. G., \& Fidell, L. S. (2001). Using Multivariate Statistics. $4^{\mathrm{a}}$ e. Needham Heights: Allyn \& Bacon.

Tan, F. B., \& Gallupe, R. B. (2006). Aligning business and information systems thinking: A cognitive approach. IEEE Transactions on Engineering Management, 53(2), 223-237.

Ullah, A., \& Lai, R. (2013). A Systematic Review of Business and Information Technology Alignment. Journal ACM Transactions on Management Information Systems, 4(1).

Urbanavicius, V. J., \& Lima, E. (2014). Conversa Estratégica e Equipes de Direção de Micro e Pequenas Empresas (Mpes). In: VIII Encontro de Estudos em Empreendedorismo e Gestão de Pequenas Empresas (EGEPE) Anais... Goiânia (GO): FACE/UFG.

Von Krogh, G., \& Roos, J. (1995). Conversation management. European Management Journal, 13(4), 390-394.

Yayla, A., \& Hu, Q. (2009). Antecedents and drivers of IT-Business Strategic Alignment: Empirical validation of theoretical model. Proceedings of the $17^{\text {th }}$ European Conference on Information Systems, Verona (Italy), June 8-10. 